\title{
Identifying with Educational Reform: British Columbia's Putman-Weir Survey
}

\author{
Katherine A. Watson, PhD \\ University College of the Fraser Valley
}

Cet article explore l'idée suivante: devrait-on s'inspirer de l'analyse généalogique de Foucault pour essayer de mieux comprendre comment il est possible que les gens soient effectivement convaincus de "s'aligner" sur certains des différents tissus subjectifs qui se constituent dans le discours? On s'intéresse à l'enquête Putman-Weir, une réforme pédagogique rédigée en 1924 par la province de la Colombie britannique, pour son utilisation créatrice d'idiomes rhétoriques et de connaissances constructives. Ces facettes sont utilisées non seulement pour discréditer l'opposition de la Commission mais aussi pour obliger le lecteur à s'identifier à la substance et aux objectifs de la réforme pédagogique. En particulier, la classification et la description des soumissions publiques à la Commission d'enquête sont analysées de façon détaillée.

This article explores the potential of utilizing Foucault's genealogical analysis to further our understanding of how it is possible that people are actually convinced to "take on" some of the various subjectivities which are constituted in discourse. The Putman-Weir Survey, a 1924 educational reform text from the province of British Columbia, is examined for its creative use of rhetorical idioms and progressive knowledge. These facets are utilized not only to discredit the Commission's opposition but also to compel the reader to identify with the substance and objectives of educational reform. In particular, the classification and description of public submissions to the Survey Commission are analyzed in detail.

In his 1997 book The Language and Politics of Exclusion: Others in Discourse, Stephen Riggins notes "[i]n general, critical discourse analysts are more interested in dissecting texts than in theorizing about the interpretive practices of readers and listeners" (Riggins, 1997, p. 3). He points out that this is an obvious though defensible limitation of the methodology of critical discourse analysis, as we need a comprehensive unpacking of the properties of any text to understand how it constrains readers' interpretations. While I agree, I believe that we need to begin to bridge the divide between textual analysis and reader interpretation. My question is therefore, as criti- 
cal discourse analysts can we more fully explore how it is possible that people (subjects) are actually convinced to "take on" some of the various subjectivities constituted in discourse. In other words, can we more fully account for how subjects are induced to identify with their subjectivity and against those they are divided from?

Despite Riggins' claim that critical discourse analysis is inconsistent with Foucault's "extreme relativism" (1997, p. 3), I demonstrate that Foucault's work on discourse is a very useful although incomplete methodological bridge between text and subject. I argue that it is possible for critical discourse analysis to construct this methodological, metaphorical bridge by utilizing Foucault's work on genealogy and by paying explicit attention to rhetorical idioms as identified by Social Constructionists such as Ibarra and Kituse (1993). Riggins himself acknowledges the importance of such idioms in his discussion of self-identity where the Self and the Other are demarcated by discourses of difference and similarity and by value judgments (1997, p.5).

In order to construct a bridge, I will examine the ways in which rhetorical idioms were utilized in a 1924 educational reform Survey Commission report in the province of British Columbia. The authors of the report, Dr. J.H. Putman and Dr. G.M. Weir, utilized these idioms to not only discredit their opposition but also compel the reader to identify with the substance and objectives of educational reform. In particular I will examine how submissions to the Survey Commission were classified and described through the use of idiom, power and knowledge.

\section{Genealogical Analysis}

Foucault (1983) argues that his work was a "history of the present" or genealogy which began by investigating processes of discursive formation and manifestations of rituals of power. These are traced to see where they emerged, "took shape, gained importance and affected politics. In short this mode of analysis asks how certain terms and concepts have historically functioned within discourse" (Campbell, 1992, p. 5). Genealogy is not easily classified as a set of methodological rules that one simply applies to the collection and analysis of data. Instead it is a mode of inquiry that focuses on historically specific discourses that provide for individual and collective identities and questions the confines of truth and order. In terms of identities, the question is not whether a free-standing human being exists, but rather how it happens that this particular (and not that) representation gets constructed. What is understood about the self at any given period of time is a matter of local practice. In a genealogical approach, the question is not "Who is Man?" but rather "Which one?" (Shapiro, 1992, p.3). Let us further consider Althusser's (1971) remarks on subjectivity: 
[Y]ou and I are always already subjects, and as such constantly practice the rituals of [discursive] recognition, which guarantee for us that we are indeed concrete, individual, distinguishable and ... irreplaceable subjects. (pp. 46-47)

Cast in these terms, the arguably spurious dichotomy (i.e., "Is the subject constitutive or constituted?") dissolves. Rigid, polarized positions are no longer the only options. A discursive theory of subjectivity can emphasize the power of language and logic to "constitute" "subjects" without running logically to the most extreme and often exaggerated position (i.e., that there are no subjects, that individuals have no power). Rather the stance Althusser suggests is that "we" (individuals, people, agents) are situated in discourse (recognizable through its language), implicated in its operations, yet still concrete individuals. The move is not to say that we have no intentionality, but rather to reveal the complexity of the interplay between discourse and subjectivity. In this light, the challenge is not to debate whether "the subject" has been erased, but rather to "trace how power circulates and surprises, theorize how subjects spring from discourses that incite them" (Britzman, 1995, p.236). In this work, I therefore investigate "the kind of people education can make" (p.237).

The poststructuralist position posits that discourses are material practices that play important roles in actively organizing social relations and meaning rather than merely reflecting an already material world (Valverde, 1991). For instance, Foucault argues that discourses produce things such as an utterance, a concept, or an effect and they constrain by attempting to confine and create parameters of practice:

Discursive practices are characterized by the delimitation of a field of objects, the definition of a legitimate perspective for the agent of knowledge, and the fixing of norms for the elaboration of concepts and theories. Thus each discursive practice implies a play of prescriptions that designate its exclusions and choices. (Foucault, 1977, p.199)

Discourses therefore help to create the frameworks in which we think and act at certain historical conjunctures. This is not a straight forward matter, however, as more than one discourse may come into play in any context and contradict the other. The result can be opposition and struggle. In addition, discourses are not fixed, but in a constant state of change. The key to this analysis is to examine the various structures, rules and sanctioned statements that are contained within any such discourse. This approach recognizes the materiality of discourse and its effects in its own right, as discourses may at times define and promote rather than only rationalize or reflect social arrangements and institutions (Goldberg, 1993, p. 95). A Foucaultian perspec- 
tive therefore directs our attention to constitutive processes of definition and articulation, and "the means through which one version of objects becomes established and alternatives undermined" (Wetherell \& Potter, 1992, p. 64).

A genealogical investigation centres on how an event, explanation or subject (referring to both individual and collective subjects) is constituted by power, 'truth' and knowledge. This is a decisive move away from looking for the underlying 'truth' of the facts toward an interest in understanding the movement and clashes of historical practices. Whether or not a discourse is 'true' is not the concern of this approach:

Truth is of the world: it is produced only by virtue of multiple forms of constraint. And it induces regular effects of power. Each society has its regime of truth, its 'general politics' of truth: that is the types of discourse which it accepts and makes function as true; the mechanisms and instances which enable one to distinguish true and false statements, the means by which each is sanctioned; the techniques and procedures accorded value in the acquisition of truth; the status of those who are charged with saying what counts as true. (Foucault, 1980 p.131)

The crucial element in this analysis is how facts, knowledge and 'truths' are constructed and what consequences result. Generally, the idea is to examine the discursive processes by which true and false statements become distinguished and how the 'truth' is institutionally sanctioned in order to produce effects.

I focus my efforts on a genealogy of educational progressivism by reading the Putman-Weir Survey for evidence of statements that are considered to be truthful knowledge. Rules, techniques and codes of disciplines such as psychology help to establish what is 'true' and 'false' and thus exclude certain knowledge. What is of interest in any regime of truth is what actually counts as truth, how other forms of knowledge are excluded from consideration and what effects are possible given these choices.

My genealogical analysis will also discuss rationalities which are generally defined as certain ways of thinking (Mills, 1997). Linked to regimes of truth, rationalities help to demarcate acceptable knowledge production. In other words, rationalities are organizing principles or provide a logic of practice. For example, a rationality of developmentalism provides classifications of stages based on a supposed progressive, linear movement. If I were to utilize this rationality, I could produce knowledge that demonstrated stages of development, whether in a child or a civilization. It is in this production and classification that I create the very thing I speak of. Foucault argues that this form of analysis enables us to understand how certain ways of thinking and acting in regard to knowledge, help to create, and not merely reflect, reality. 
Regimes of truth and rationalities help to impose order and create categories, thus limiting and excluding some knowledge and 'truths' while emphasizing others. Both help to produce our "vision" of educational reform while at the same moment narrowing our sight to only a few options in regard to what counts as educational reform. This form of analysis also argues that each statement leads to others. So, for example, if the "problem" of education is defined in a particular way, then there are only so many potential solutions. What counts as an educational "problem" in the first place is informed by the 'truth' and knowledge of, in this case, progressivism.

Despite this approach's strength and ability to render practices of reform visible, there exist many critiques of this mode of analysis (see for example Dreyfus \& Rabinow, 1983; Taylor, 1986; Fairclough 1992; Mills, 1997). I emphasize three critical points that build on Foucault's position by modifying and improving the complexity of his analysis. The first has to do with the apparent imposition of discourse onto persons without a full accounting of resistance. Although there is room for opposition in Foucault's work, it often appears that people are "victims" and structurally determined by discourses beyond our control. Many Feminist theorists have taken issue with this point in particular and scholars such as Dorothy Smith (1990) and Judith Butler (1990) have argued that discursive constraints are often negotiated and subjectivity is "performed" rather than simply imposed. This allows for the space of alternative, unstable constitutions of subjects rather than fixed entities.

Sara Mills (1997) also argues that we need to emphasize the various aspects of resistance that can be read in texts. For example, if we view femininity as discourse then rather than seeing advice manuals for women as being an indicator of their oppression, we can instead view the manuals as an "indication of the scale of the problem posed by women and their resistance in being counselled in this way" (Mills, 1997, p. 88). By emphasizing the complexity of subjectification and resistance, these scholars (and many others) offer a modification to genealogical interpretation that focuses on contestation and the context of conflictual relations of any particular discourse.

While the first modification points to the importance of resistance, the second modification attempts to answer how it is possible that people are actually convinced to take on some of the various subjectivities constituted in discourses. The two points can be seen to complement one another as we can explore how is it possible to be divided from some identities and resist, while also being induced to identify with others. It is here that a genealogical approach can benefit from the Social Constructionist approach to rhetoric.

Social Constructionists examine what "claims-makers" say and do to convince an audience that troublesome conditions exist (Loseke, 1999). The Constructionists' overriding concern is not whether a claim is true or false, but with how humans create 
meaning. In addition, they recognize that there is competition amongst various claimsmakers who employ different strategies, such as creating "villains" and "victims." A hierarchy of credibility is also discussed as a way that claims-makers can legitimate their views. Much of this sounds very similar to a genealogical approach, but Constructionists begin from a very different epistemological base.

According to Loseke (1999), Constructionists see themselves and their work as value-neutral and scientific and language as a "real" representation of the world. Language for Constructionists, therefore, reflects experience, rather than being viewed as a material practice which helps to constitute "reality." Another difference is that for a Constructionist claims-making is individualized and attributed to personal motives or self-interest, rather than structure and context.

A genealogical approach does share the Social Constructionists' view that determining the ultimate 'truth' of a claim is not of concern. However, those utilizing genealogy are interested in how 'truth' claims are constructed within a discourse. How we critique an event or activity, and on what we base that critique, tells us a great deal about the ways in which we determine what counts as 'truth' and knowledge at any given time and place. Understanding the discursive processes of 'truth', in turn, leads us to analyze relations of power that are constraining and productive at the same moment. This is a far cry from the Social Constructionist position that a hierarchy of credibility determines legitimacy or that individualized strategies simply produce types of people. Rather, a genealogical interpretation sees problematization as being informed by a complex array of discursive structures which are embedded in social and historical contexts.

Despite the differences between these two perspectives, a genealogical approach can benefit from the social constructionist methodology of the rhetorical dimensions of claims-making. According to Ibarra and Kitsuse (1993), rhetoric consists of constitutive techniques and processes of speaking and reasoning. Their particular focus is on the construction of social problems and, as such, how people become participants in any social problems discourse. For instance, rhetorical idioms are commonsense constructions of morality which endow claims of social problems with significance by incorporating particular values and calling forth images and symbols that evoke feeling (pp. 35-36). These idioms clarify an "ethos implicit in the claim. This is especially facilitated by each idiom's characteristic set of positive and negative terms, that is, the idiom's preferred objects of praise and scorn" (p. 36). The rhetoric of discourse therefore encourages participants to be sympathetic to the claims being made and to structure their own claims along the same line and not others.

By incorporating an analysis of rhetoric from the Social Constructionist perspective, it is possible to address a missing component of genealogy, namely, an ac- 
count of how subjects are induced to identify with their subjectivity and against those they are divided from. In other words, it is one thing to create the frame of possibilities and actions discursively, but it is another to persuade persons to "take up" or activate their subjectivities in particular ways. A central component of discourse is its constitutive capacity to not only divide and classify reality, but also its capacity to get us to embrace these categories as our own, making them real and effective. It is the rhetorical aspects of discourse that allow for this to happen. The Putman and Weir Survey uses several rhetorical devices to discredit its opponents while urging its reader to identify with its claims and the aims of the report.

The third modification is based on Norman Fairclough's (1992) argument that texts are open to various interpretations and that often their meaning is unclear and ambivalent. This is especially the case in media analysis when it is uncertain who is speaking as voices within the text become blended with that of other official documents (p. 110). He argues that by focussing on the contradictions, disjuncture and ambivalence of discourses, we get a better picture of the complexity of how discourses affect social subjects. This extends my own analysis by being aware of instances of resistance and contradiction, and by remaining open to the various meanings that the text conveys. Not everything in a text is unproblematic or transparent and consideration should be given to the silences as well as the present structures and utterances throughout the text of the Putman-Weir Survey.

These three aspects provide for a more critical approach and help to bridge some of the gaps left in Foucault's work. Though far from a complete overhaul of genealogy, the emphasis on resistance, rhetoric and textual ambivalence supplement the strengths of this approach and provide for a more complete and interesting assessment of the Putman-Weir Survey in British Columbia.

\section{Classes of Public Opinion}

The British Columbia Department of Education announced in April 1924 that an educational survey commission (similar to a commission of inquiry) would be conducted in order to investigate a broad range of educational issues in the province. Although officially entitled Survey of the School System of British Columbia, it would soon become known as the Putman-Weir Survey after its Commissioners. Guided by a framework of nineteen questions that focussed primarily on reforming the public school system, the Commission travelled 9500 miles throughout the province holding 215 conferences and inspecting 160 public schools and two normal (teacher) schools. The survey was, up until then, the largest single study ever conducted in Canadian education. It is still considered one of the most important documents dealing with educational reform in British Columbia. 
The Survey is also a pivotal text which outlined the discourse of progressive educational reform in British Columbia. Putman and Weir referred to progressivism as a type of "educational thought" which advocated school innovation and advancement in order to educate the future citizens of the province. Included in their list of innovations were the systematic use of standardized tests, efficiency of instruction, vocational guidance, expanded technical education, the use of general taxation to support the system and the adoption of junior high schools. These reforms were thought to enhance 'the whole child' and to accommodate the developmental needs of every individual child (1925, p.27).

Putman and Weir would utilize the "truths" of progressivism and science to undermine, discredit and divide their opponents. Those who complained about "frills" and educational costs were ignorant, greedy and ultimately undermined the 'nation':

In certain instances the noisy and irresponsible critic of modern movements in education finds much to rail at in the field of educational finance. Ignorance and dogmatism usually go hand in hand and constructive criticism is precious as it is rare. Fortunately, the irresponsible type of critic belongs to a relatively small minority. (Putman and Weir, 1925, p. 5)

Putman and Weir argued that mere opinion could not form the basis of educational policy as many (especially their opposition) of those who offered an opinion on educational problems were simply mired in "prejudice and local self-interest." Given the importance of education to the 'nation,' only the scientific evidence gathered by trained educational experts, such as themselves, could help to form policy and educational practice. The Commission's use of "science" to legitimate its reforms also aimed to discredit its opponents. As well, the categories that Putman and Weir formulate to discredit their opponents are rhetorical devices. They use rhetorical idioms which construct the various positions on reform in both positive and negative ways. This is a clear attempt to induce the reader to identify with the aims of the report and against the opposition and will be explored in more detail.

Attempting to discredit their opposition, Putman and Weir divided their opponents by categorizing their public submissions into a continuum of "five main divisions for purposes of comment and comparison" (Putman and Weir, 1925, p. 24). These five classes of submissions (not all of which were labelled as oppositional), consisted of a) Reactionary and Ultra-conservative; b) the Conservative Class; c) the Moderate Class of Educational Opinion; d) Progressivism; e) Radicalism (Putman and Weir, 1925, pp. 24-27). Importantly, those who made submissions had no voice or say in how the Commission categorized and represented their "opinions." These categories therefore tell us a great deal about the Commissioners, but very little about 
those whom they sought to categorize, as they were effectively lumped together, stereotyped, and ultimately silenced.

Despite admitting that the divisions were not mutually exclusive, Putman and Weir constructed these categories based on what they argued was an objective analysis (1925, p. 24). Three main progressivist assumptions were applied as the criteria to classify the submissions. The first was whether or not the submission recognized the need to modernize existing educational practices and to what degree. The second was whether or not the submission supported free education or wanted to impose school fees. The third, though not equally applied, was how the submission viewed the objectives or purpose of education. After each submission had been assessed on the basis of these criteria, it would be placed in one of the five categories along the continuum.

The first category, "reactionary and ultra-conservative" consisted of the opposition which the Survey wanted to discredit the most. It received the most attention in the report. None of it was good. Although it was characterized as a "distinct minority," its numbers and influence were obviously viewed as significant. The submissions that were placed in this category were characterized as arguing against modern or progressive reform by extolling what Putman and Weir referred to as "the fetish of the 'little red school house' of the nineteenth century or earlier, while the slogan adopted appears to be 'Away with the frills and fads and back to the three R's' " (Putman and Weir, 1925, p. 24). Supporters of this view also reportedly favoured charging fairly large high school fees, excluding those students from high school who did not show intelligence and progress in their studies, and excluding certain subjects from the curriculum. Putman and Weir argued that those who supported this view had demonstrated "much loose thinking" as they never clearly identified who or what precisely should be excluded (Putman \& Weir, 1925, p. 24).

Part of the "reactionary" argument for exclusiveness rested upon the belief that too many students were being prepared for "white-collar" work, leaving an insufficient number to perform "manual tasks and menial service." Putman and Weir argued against the exclusion of future manual or service workers from a high school education by rhetorically aligning their Progressive position with the needs of a modern civilization, business and democracy:

... it is surely obvious, both from the viewpoint of the employer and the employee, that a high school education, of a practical or vocational turn, would prove an asset to the future plumber, bricklayer, miner, farmer, lumberman, or other labourer ... In the increasing complexity of our modern civilization a high school education is rapidly coming to be rec- 
ognized as a necessity for the achievement of success and not a mere luxury. In an autocracy, such as Prussia of ten years ago, the process of class selection (and subjection) might solve the problem of occupational placement ... but it is no longer fashionable to extol Prussian standards ... Democratic thinkers believe, rightly or wrongly (the Survey believes rightly) in ... "equality of opportunity" ... within the limits prescribed by intelligence, moral worth, industry and aptitude. The great majority of the citizens of British Columbia will no doubt agree with the view ... that 'A square deal in adult life is not worth much unless there is a fair chance during childhood'. This doctrine of the "square deal" is essentially British. (Putman \& Weir, 1925, pp. 25-26)

Characterizing their opponents as elitist, Putman and Weir also strategically claimed that these people extolled values similar to the Prussians, "the enemy" whom the Empire had defeated only seven years before in the Great War. This quickly became a patriotic, almost militaristic defence which sought to secure the place of progressive reforms as democratic and British: perhaps a metaphor for everything that was deemed good, right and victorious. Again, reform of the public schools, when presented in this light, was simply the right thing to do. And the opposition was simply wrong and obviously bad, almost like the enemy that had been defeated. This strongly moralistic language could invoke emotion and compel many to identify with the reformers and the aims of the report. After all, wasn't the Great War all about civilization and Empire?

Putman and Weir continued with their scathing attack by further characterizing the critics as "cynical materialists" and "amateurish educational diagnosticians" who were "dangerous" if given their way, and whose "clamour" was out of proportion with their importance (Putman \& Weir, 1925, p. 26).The Commission declared that "the pious ejaculation of 'being old-fashioned enough' is but a disguise to conceal ignorance and mental inertia under a veneer of assumed respectability" (Putman \& Weir, 1925, pp. 42-43).

Putman and Weir also linked the class of "reactionaries" with "traditional" objectives in education. Traditionalism, Putman and Weir charged, was informed by "functional or faulty psychology" which supported traditional objectives for education. Simply stated, this position assumed that

... there may be a transfer of training or improvement from one field to another without specific exercise in the latter. In British Columbia, for instance, a more comprehensive study of history was frequently urged before the Survey as efficacious in improving the memory and judge- 
ment, not merely the memory for history but for things in general. (Putman \& Weir, 1925, p. 40)

Such courses as Latin were therefore highly regarded by the traditionalists. Latin was said to improve all faculties of the mind, such as memory, reasoning and imagination. The Commission labelled this theory as the "formal discipline doctrine." This 'truth' reportedly became the rationale for many who opposed progressive reforms, as it supported the view that the existing basic academic program in the schools was completely adequate and in no need of reform. In British Columbia, this view or "doctrine" had previously been used in the system to determine the basis and limitations for the curriculum:

New subjects of study have been added in spite of its influence and in opposition to the formal disciplinarians, whether among teachers or laity, who are inclined to attack the inclusion of such subjects as domestic science or manual training in the same category with the time honoured classics and mathematics. The influence of this doctrine is also evident among large numbers of the ratepayers who regard education chiefly as learning out of a book. If the teacher drills incessantly on the formal parts of grammar and arithmetic or the facts of history and geography, he [sic] is in their opinion, a good teacher. It is also this doctrine of formal discipline that the reactionaries and the conservatives in educational thought chiefly appeal as a buttress of their conservatism. (Putman \& Weir, 1925, p. 42)

It would be irrational and unwise to change, as it might invite "trouble and unrest" according to this position. The unrest and trouble were not specified, but the traditionalist logic and the knowledge they relied upon were quite clear, despite the attempts to undermine them. I do not doubt that those who opposed progressivism on this basis did not see themselves as following "doctrine" or would necessarily call themselves "traditional," but I have no evidence of this. These terms were "loaded" in the sense that they were used by the Commission to further discredit its opposition. The progressive reform position was reinforced as the normal and the conservatives as deviant and misinformed cynics. The rhetoric is exceedingly clear.

The other problem, according to Putman and Weir, was that this theory which the opposition relied upon had been scientifically disproved and was therefore only creating an "intellectual torpor" which needed to be swept away in the face of the constantly changing needs of modern life. As evidence, Putman and Weir examined Professor E.L. Thorndike's study of whether studying Latin and mathematics over 
French or physics improved individual intelligence in order to discredit the traditionalist position and support their own progressivist position:

Twenty years ago the brighter students in our secondary colleges and universities specialized largely in classics and mathematics. A false process of reasoning established a causal relationship where none existed, and assumed that the study of these branches of culture made the students more clever. At the present time the more able thinkers are studying the sciences, possibly owing to economic reasons. Obviously it would be a similar fallacy to assume that sciences possess an inherent mental disciplinary value superior to that alleged to be derived from the study of classics. (Putman \& Weir, 1925, p. 41)

Their science was poor, their values elitist, even Prussian in nature. They were undemocratic, cynical and even dangerous. They also created stagnation and undermined the 'nation.' The "reactionaries" were indeed a difficult bunch who resisted progressivism and offered an alternative view of education, psychology and 'the pupil.'

This contest of 'truths' demonstrates the different educational realities and knowledge that existed in the Province at this time. It also demonstrates the struggle it took for progressivism to become dominant as the Commission went to such lengths to discredit an opposition which existed both in the schools and in the public at large. Changing the basis on which educators had for years been making decisions about pupils and practices was no easy feat.

The Commission was challenging the opposition (which up until this point had been the dominant discourse of education) based on the standards of progressivism. The opposition, if it wanted to continue the debate and remain legitimate, had to "answer" on the Commission's terms. Opponents had to argue that they are indeed democratic, British, moral and have adequate scientific evidence. Those holding alternative views were now obligated to legitimize themselves on these terms. As progressivism came to colonize the educational space in the province, alternative ideas had very little room. Demonized and discredited, the "reactionaries" were dismissed.

Putman and Weir's second category of submissions, labelled the "conservative class," was characterized as less extreme and reactionary than the first category. These submissions did not pay "mystic homage" to the past, but they did consider it "unsafe to cut themselves too hastily from its moorings" (Putman \& Weir, 1925, p. 26). Also against "frills" in the school curriculum, they couldn't agree amongst themselves as to what constituted a "frill," although they often mentioned household science, manual training, art and music. They also supported a "moderate" high school fee to stimulate an appreciation of high school by the students and their parents. Despite these 
"shortcomings," they at least agreed to some modification of educational institutions in light of modern standards. This raised their standing, according to the progressivist criteria, above the "reactionaries." Painted as more moderate, less dogmatic and somewhat rational by Putman and Weir, this "conservative" class recognized modern circumstances, and therefore the report treated them considerably less harsh and critically; for this class there was no incantation of nationalism, democracy, and "the British way."

The third class of public opinion was labelled as "moderate." Here was a good, rational grouping of people if ever there was one. The rhetoric of this category creates the image of morality and moderation inducing people to align themselves with its claims.

The exponents of moderation in educational expansion and practice have no fetishes nor retrenchment slogans so far as free high school education or the subjects of the school programme are concerned. They insist, however, that the curriculum is somewhat old-fashioned and in need of expert revision. The middle or junior high school and vocational education, within reasonable limits are regarded with considerable favour. It is contended, however, that caution and prudence should be exercised in the development of our educational institutions and that close scrutiny should be applied to all expenditures of a possibly extravagant character. This class asks for reasonable economy in school expenditures ... apparently [this class] constitute a majority of the citizens of the Province. (Putman \& Weir, 1925, p. 27).

Most citizens were therefore reasonable, cautious, prudent and recognized the importance of expertise. This group was everything the first two groupings were not. The Commissioners did not need to convince or critique this group; the majority (which always carries the day in the best British Parliamentary way) of citizens was naturally inclined this way and thus supported moderate progressive reforms within prescribed limits. "The good citizen" was therefore cast as "no true citizen advocates extravagant expenditure for school or other purposes" (Putman \& Weir, 1925, p. 34). Moderate citizens were therefore conceived as better, normal individuals, as the very ideals of the nation, civilization and Empire were intrinsic features of these subject positions. Only elitist cynics would not want to be moderate. Interestingly, as long as "opinion" bowed to expertise and was not at cross purposes to progressivism, it suddenly became legitimate. This was based strictly on moderation and majority rule with no mention of scientific investigation or gathering of data being called for to test this "mere" opinion. 
Putman and Weir also associated this class of "moderate" opinion with a composite view of modern and traditional educational objectives (Putman \& Weir, 1925, p. 35). These objectives included patriotic ends of instruction, individual development, specific habit formation and the development of character. These composite objectives nevertheless contrasted with the traditional aims of the "reactionaries," particularly in the type of values that this imagined nation should contain:

The development of a united and intelligent Canadian citizenship actuated by the highest British ideals of justice, tolerance, and fair play should be accepted without question as a fundamental aim of the provincial school system. Such an aim has stood the test of time and its application in the daily lives of the British peoples has enhanced the good name of the British Empire. (Putman \& Weir, 1925, p. 38)

Appealing to both "Canadians" and those who aligned themselves with the British Empire, the composite position offered something quite different from Prussian elitism. Putman and Weir argued that the vast majority of submissions contained both traditional and modern objectives (Putman \& Weir, 1925, p. 35). Moderation seemed to be a very contradictory place where the best of both worlds could be embraced; hold onto the Empire but move forward into the future.

Putman and Weir labelled a fourth class of public opinion as "progressivism." This class was associated with the majority, "moderate" position as "[ $t$ ] he more moderate school of thought ... also sanctions some of the above [progressive] "innovations" in our schools, but within more restricted limits" (Putman \& Weir, 1925, p. 27). Progressivism apparently only needed some limits to its enthusiastic, innovative plans of reform. Putman and Weir argued that "the great majority of this class are not owners of property," thus explaining why people associated with this class of opinion apparently lack a sense of prudence. By implication, the "moderate" majority were owners of property which had tempered their opinion, making them more responsible and more practical.

This class of public opinion was also linked to what Putman and Weir called "modern educational objectives." This position portrayed quite a different understanding of who the pupil was, and what would benefit him or her.

Education is life, not a mere preparation for life consisting in the memorization of facts and principles and the mastery of formal curriculum. Furthermore, life is real throughout and no artificial distinctions between the so-called preparation period of childhood and the alleged realization period of adult life should be set up. Many academic schools 
with their traditional curricula and formal methods of instruction have consistently ignored the admonitions of such educational philosophers as Rousseau, Dewey, and others, with the result that failure is written across the record of their activities. Such modern types of school organization as the junior high school have come to the rescue in their attempt to put a little more life in education as well as more education in life. (Putman \& Weir, 1925, p. 44)

The modern practices and objectives of the progressives would therefore 'truly' educate and prepare pupils for a successful life. This was very different from the rote learning and approach of the traditional "reactionaries." This quote illustrates the central concern of the modern Progressive movement - the fostering of life itself, through the care and growth of the population.

The rationality of government is at work here as the school, and indirectly the state, seek to organize pupils' very lives, governing them toward certain identities and ways of being. This illustrates Foucault's point that modern forms of power can be positive and productive, operating primarily through the organization of life rather than through coercion and the threat of death (Dreyfus and Rabinow, 1983).

The final class of public opinion was labelled by Putman and Weir as "radicalism." An even smaller group of ratepayers than the "reactionaries," it was argued that this class resembled its extreme opposite in some ways:

Each aims at demolishing, to a large extent, and reconstructing many features of existing educational institutions, but this course is advocated from entirely different points of view. The materials and methods of reconstruction are also radically at variance. The exponents of the radical school of educational reform look to the future for the promise of a new era of greater opportunity, and, as one means of ushering in this halcyon period would revolutionize the educational programme from top to bottom. The reactionary school turns just as ardently to the past, as an era of educational self-sufficiency and by a process of devolution (or excision) would simplify the educational programme, academic and administrative from top to bottom. (Putman \& Weir, 1925, p. 27)

Those in the "radical" class were reported to have argued that the curriculum needed to become even more attuned to modern needs through such things as economic studies so that people might "protect themselves against the wiles and intrigues of the 'interests"' (Putman \& Weir, 1925, p. 28). Discredited by association with "the reactionaries," Putman and Weir paid little attention to "the radicals." If members of 
this class had communist or socialist leanings, it was never mentioned and the "red scare" never invoked. Obviously Putman and Weir did not perceive them as a threat since they had little impact on public opinion or on the proceedings.

In wrapping up their discussion of classes of public opinion, Putman and Weir clearly favoured the moderate position, reinforcing its connection to Britain, stability, wisdom and efficiency:

The stabilizing factor is obviously to be found in class (c), representing the moderate group of educational opinion. The adherents of this group, roughly, fifty per cent of the taxpaying body cannot be easily stampeded by extreme viewpoints from either quarter ... Wise expenditures must be applied in accordance with sound educational objectives chosen to satisfy real social needs rather than to secure fanciful innovations. The limits of the public purse are recognized as the factor governing educational expansion, since no self-respecting people who profess to pay their way are entitled to a better system of education than they can afford to support ... At the same time it is just as readily conceded that cheap inefficiency in public education is less economical in the long run than more costly (for the immediate present) efficiency. Since majority rule is paramount in British communities, when the "moderates" move forward educationally, the financial interests must pay their share. Nor will the latter object, unless in cases of an indifferent or absentee "aristocracy" if the wisdom of the investment is clearly established ... the opinion is confidently advanced that those who have amassed their wealth in the competition of modern commerce and industry should be among the first to admit that the demands of our complex civilization with its numerous and intricate contacts - social, national, political, economic, and international - cannot be adequately met by the traditional school organization designed for the more primitive social groupings of a generation ago. (Putman \& Weir, 1925, p. 28)

The logic behind the expansion and reformation of state schooling therefore becomes obvious. Putman and Weir argued that they were addressing "real social needs" to modernize school practices in order to ready future citizens for the rigours of tomorrow. These "real social needs," however, were constituted by the progressivist discourse of evaluating past educational practices as insufficient for modern conditions. However, the composite educational objectives associated with "the moderates" were made up of both traditional and modern aims which seem contradictory given the justification for reform initiatives. Character development, patriotism and 
Empire were rooted in British tradition and yet were not abandoned despite modernization. There are two possibilities that may explain this.

The first could be that the discourse of nationalism was so completely dominant at this time that it had to permeate the text in order for officials and ordinary citizens to support any educational reforms. This is a plausible explanation given that the Great War had only ended seven years before and could be used as a rallying point. The other possibility is that the "imagined" nation of British Columbia was so precarious and so problematic that it needed to be reinforced in schools. If patriotism and community were 'natural', then why emphasize them so much? This text could therefore be an indication of the scale of the problem posed by some people in British Columbia in the 1920 sho simply did not act in accord with the values of this "imagined" community. The continuation of British tradition hardly seems modern, and yet this contradiction was embraced by Putman and Weir. Exactly why remains an open question.

By constructing the categories of public opinion in this way Putman and Weir utilized rhetorical devices to discredit their opposition and to associate progressivism with everything deemed good and right and just. This is a clear attempt to induce the reader to identify with the aims of the report by persuading them of the morally correct stance of the progressive, moderate and modern approach to schooling in British Columbia.

This particular study of educational reform points to the potential of utilizing a genealogical analysis of text while paying close attention to the rhetoric of value judgements that induce identification and separation. This investigation therefore begins to build the bridge between the divide of textual analyses and reader interpretation of discourse.

\section{REFERENCES}

Althusser, L. (1971). Essays on ideology. London: Verso.

Britzman, D.P. (1995). The question of belief: Writing poststructural ethnography. International Journal of Qualitative Studies in Education, 8, 229-238.

Butler, J. (1990). Gender trouble: Feminism and the subversion of identity. New York: Routledge.

Campbell, D. (1992). Writing security: United States foreign policy and the politics of identity. Minneapolis: University of Minnesota Press.

Dreyfus, H.L., \& Rabinow, P. (1983). Michel Foucault: Beyond structuralism and hermeneutics. (2nd ed.) pp. 229-252. Chicago: University of Chicago Press. 
Fairclough, N. (1992). Discourse and social change. London: Polity.

Foucault, M. (1977). History of systems of thought. In D.F. Bouchard, (Ed.), Language, counter-memory, practice. (pp. 199-204) Ithaca, NY: Cornell University Press.

Foucault, M. (1980). Truth and power. In C. Gordon (Ed.), Power/Knowledge: Selected interviews and other writings 1972-1977 by Michel Foucault. New York: Pantheon Books.

Foucault, M. (1983). Afterword: The subject and power. In H.L. Dreyfus \& P. Rabinow, Michel Foucault: Beyond structuralism and hermeneutics. (2nd ed.) pp. 229-252. Chicago: University of Chicago Press.

Goldberg, D.T. (1993). Racist culture: Philosophy and the politics of meaning. Oxford: Blackwell Press.

Ibarra, P.R., \& Kituse, J.I. (1993). Vernacular constituents of moral discourse: An interactionist proposal for the study of social problems. In J.A. Holstein \& G. Miller (Eds.), Reconsidering social constructionism: Debates in social problems theory. New York: Aldine De Gruyter.

Loseke, D. (1999). Thinking about social problems: An introduction to constructionist perspectives. New York: Aldine De Gruyter.

Mills, S. (1997). Discourse. New York: Routledge.

Putman, J.H., \& Weir, G.M. (1925). Survey of the school system of British Columbia. Victoria, BC: King's Printer.

Riggins, S. (1997). The language and politics of exclusion: Others in discourse. Thousand Oaks, CA: Sage Publications.

Shapiro, M.J. (1992). Reading the postmodern polity: Political theory as textual practice. Minneapolis: University of Minnesota Press.

Smith, D. (1990). Texts, facts and femininity: Exploring the relations of ruling. New York: Routledge.

Taylor, C. (1986). Foucault on freedom and truth. In D. Couzens Hoy (Ed.), Foucault: A critical reader. Oxford: Blackwell Press.

Valverde, M. (1991). The age of light, soap, and water: Moral reform in English Canada, 1885-1925. Toronto, ON: McClelland and Stewart Inc.

Wetherell, M., \& Potter, J. (1992). Mapping the language of racism: Discourse and the legitimation of exploitation. New York: Columbia University Press. 